\title{
Australian Hajj pilgrims' knowledge, attitude and perception about Ebola, November 2014 to February 2015
}

A S Alqahtani (amani.shelwa@gmail.com) ${ }^{1,2}$, K E Wiley ${ }^{1,2}$, H W Willaby ${ }^{1,2}$, N F BinDhim³, M Tashani ${ }^{1}$, A E Heywood ${ }^{4}$, R Booy ${ }^{1,5}$, H Rashid ${ }^{1}$

1. National Centre for Immunisation Research and Surveillance of Vaccine Preventable Diseases (NCIRS), The Children's Hospital at Westmead, and the Discipline of Paediatrics and Child Health, Sydney Medical School, University of Sydney, Australia

2. School of Public Health, University of Sydney, Sydney, Australia

3. Health Informatics department, Saudi Electronic University, Riyadh, Saudi Arabia.

4. School of Public Health and Community Medicine, University of New South Wales, Sydney, Australia

5. Marie Bashir Institute for Infectious Diseases and Biosecurity, School of Biological Sciences and Sydney Medical School, University of Sydney, Sydney, Australia

Alqahtani AS, Wiley KE, Willaby HW, BinDhim NF, Tashani M, Heywood AE, Booy R, Rashid H. Australian Hajj pilgrims' knowledge, attitude and perception about Ebola, November 2014 to February 2015. Euro Surveill. 2015;20(12):pii=21072. Available online: http://www.eurosurveillance.org/ViewArticle. aspx?Articleld $=21072$

Upon return from Hajj 2014, 150 Australian pilgrims were interviewed about their understanding of the Ebola epidemic. Most $(89 \%, 134 / 150)$ knew of the epidemic before travelling and $60 \%(80 / 134)$ of those knew Ebola transmits through body fluids. Pilgrims who received pre-travel health advice were more conscious of Ebola ( $69 \%$ vs $31 \%, p=0.01$ ) and adhered better to hand hygiene after touching an ill person $(68 \%$ vs $31 \%$, $p<0.01)$. Mass media was the main information source $(78 \%)$.

As the largest known, the 2014 Ebola outbreak has affected more than 24,700 people in the three most affected West African countries, claiming ca 10,200 $(41 \%)$ lives $[1,2]$. With ca 100,000 pilgrims from those affected countries attending Hajj each year, the possible introduction of Ebola to a Hajj event could be catastrophic. To minimise the risk, the Saudi Arabian authorities suspended Hajj visas for pilgrims from the affected countries and at the time of publication of this report, no Hajj-associated Ebola case has been reported [3]. Without an effective vaccine, public awareness of the need to avoid exposure through minimising contact with patients and body fluids, using personal protective measures, and cancelling non-emergency travel to affected countries remain the mainstays of prevention [4]. However, travellers' awareness about Ebola has not been assessed. We conducted a short survey among Australian pilgrims returning from Hajj 2014 to assess their knowledge about Ebola, its mode of transmission, and their compliance to preventive measures during Hajj.

\section{Survey}

Between November 2014 and February 2015, an anonymous cross-sectional survey was conducted among Australian pilgrims returning home from Hajj in October 2014. Participants were recruited by two methods: pilgrims attending post-Hajj seminars or social gatherings in New South Wales were invited to participate in person; other Australian pilgrims were invited to participate by telephone. The latter group were randomly chosen from a list of participants who took part in an ongoing cluster randomised trial during the Hajj 2014 which has been described elsewhere [5].

The questionnaire collected data on socio-demographic characteristics, travel itinerary, pre-travel health advice, pilgrims' knowledge on Ebola, and compliance to protective measures such as hand hygiene and use of face masks. Pilgrims' knowledge and attitude about Ebola were assessed through five questions: (i) whether the pilgrims had heard about Ebola before their travel; (ii) their knowledge on Ebola transmission; (iii) how serious they thought Ebola was; (iv) how concerned they were about contracting Ebola during Hajj; and (v) their perceived risk of Ebola at Hajj.

Participants' voluntary completion of the questionnaire was implicitly considered as consent and the survey was anonymous. This study was approved by the Human Research Ethics Committee (HREC) at the University of Sydney (Project no: 2014/599).

\section{Knowledge, attitude and perception} regarding Ebola among Hajj pilgrims A total of 150 pilgrims participated. They were between 18 and 72 years old (median: 41 years), and $46 \%$ (69/150) were male. Half (75/150) had a university degree and about two thirds (96/150) were employed. One third (49/150) of the participants had pre-existing chronic medical conditions (Table 1). Seventy-nine per cent $(119 / 150)$ of respondents performed Hajj for the first time, $7 \%(10 / 150)$ for the second time and $16 \%$ (24/150) had attended Hajj more than twice. 


\section{TABLE 1}

Demographic characteristic and knowledge about Ebola of survey participants, Hajj pilgrims, New South Wales, Australia, November 2014-February 2015 ( $\mathrm{n}=150)$

\begin{tabular}{|c|c|c|}
\hline & n (\%) & $\begin{array}{l}\text { Had knowledge } \\
\text { about Ebola }\end{array}$ \\
\hline \multicolumn{3}{|l|}{ Age (years) } \\
\hline $18-30$ & $28(19)$ & $25(89)$ \\
\hline $31-45$ & $75(50)$ & $72(96)$ \\
\hline $46-65$ & $39(26)$ & $33(85)$ \\
\hline$>65$ & $8(5)$ & $3(38)$ \\
\hline \multicolumn{3}{|l|}{ Sex } \\
\hline Male & $69(46)$ & $66(96)$ \\
\hline Female & $76(51)$ & $66(87)$ \\
\hline \multicolumn{3}{|l|}{ Co-morbidities } \\
\hline Diabetes & $5(3)$ & $3(60)$ \\
\hline Asthma & $9(6)$ & $8(89)$ \\
\hline Lung diseases & $3(2)$ & $3(100)$ \\
\hline Heart diseases & $1(1)$ & $1(100)$ \\
\hline Cancer & $3(2)$ & $3(100)$ \\
\hline \multicolumn{3}{|l|}{ Education level } \\
\hline None & $5(3)$ & $3(60)$ \\
\hline $\begin{array}{l}\text { School certificate (year } 10 \\
\text { equivalent) }\end{array}$ & $11(7)$ & $11(100)$ \\
\hline High school (year 12 equivalent) & $22(15)$ & $19(86)$ \\
\hline Certificate/diploma & $32(21)$ & $28(88)$ \\
\hline University degree & $47(31)$ & $43(91)$ \\
\hline University postgraduate degree & $28(19)$ & $28(100)$ \\
\hline \multicolumn{3}{|l|}{ Occupational status } \\
\hline No & $49(33)$ & $41(84)$ \\
\hline Yes & $96(64)$ & $91(95)$ \\
\hline \multicolumn{3}{|l|}{ Occupational type } \\
\hline Self-employed & $17(11)$ & $17(100)$ \\
\hline Full time & $61(41)$ & $57(93)$ \\
\hline Casual & $4(3)$ & $4(100)$ \\
\hline Part time & $14(9)$ & 13 (93) \\
\hline
\end{tabular}

Sixty-six per cent (99/150) reported receiving general health advice before Hajj; $20 \%(n=30)$ from travel agents, $16 \%(n=24)$ from general practitioners, $6 \%$ $(n=9)$ from the Internet, $6 \%(n=9)$ from friends and family members, $4 \%(n=6)$ from the smarttraveller website (http://www.smartraveller.gov.au), 3\% $(n=4)$ from professional travel health services and the remaining $11 \%(n=17)$ from other sources.

Eighty-nine per cent (134/150) of participants had been aware of the current Ebola outbreak before travelling. Of these, 78\% (105/134) reported the mass media as their main source of information, followed by the Internet ( $9 \% ; n=12)$, general practitioners (GPs) $(6 \%$; $n=8)$, friends and family members $(5 \% ; n=6)$ and travel agents $(1 \% ; n=2)$.

Respondents aged 45 years and younger were more aware of the epidemic than older respondents ( $94 \%$ vs $76 \% ; \mathrm{p}<0.01)$, and those with a university education were more aware of Ebola than those with less education ( $54 \%$ vs $46 \% ; p=0.05)$. Pilgrims who sought health advice before travelling were more conscious of Ebola than those who did not seek such advice (69\% vs $31 \% ; p=0.01$ ).

Of those who had heard of Ebola, $60 \%(80 / 134)$ stated that the virus transmits through contact with infected body fluids, $17 \%(n=23)$ said it spreads through air, $1 \%$ $(n=1)$ believed it transmits through contaminated food, whereas $22 \%(n=30)$ did not know how it transmits.

Eighty-six per cent (115/134) of participants thought that Ebola is a serious and life-threatening disease, $4 \%$ $(n=6)$ thought it is serious but not life-threatening, $1 \%$ $(n=1)$ said it is minor infection and $7 \%(n=10)$ did not know if it is serious.

Twenty-two per cent (29/134) of those who were aware of Ebola believed there was no risk of contracting it during Haji, 38\% ( $n=51)$ thought the risk was low, $19 \%$ $(n=26)$ considered it a moderate risk and $21 \%(n=28)$ believed the risk was high. Nevertheless, $45 \%(60 / 134)$ were not concerned of contracting Ebola during Hajj, while $29 \%(n=39)$ were slightly concerned, $8 \%(n=11)$ were moderately concerned and $18 \%(n=24)$ were very concerned.

Regarding preventive measures during their tent stay in Mina, Saudi Arabia, about half of the participants reported using face masks, most reported washing hands with plain water and two thirds reported using soap (Table 2). More than half ( $55 \%$ ) reported washing their hands after touching an ill person. Those who sought health advice before travelling were more likely to practice hand washing ( $97 \%$ vs $88 \%, p=0.03$ ), especially after touching an ill person $(68 \%$ vs $31 \%$, $\mathrm{p}<0.01)$.

Of those who observed hand hygiene, $66 \%(98 / 148)$ believed it to be an effective method of preventing infections and $36 \%(53 / 148)$ considered it easy to implement. Of those who used face masks $61 \%$ (50/82) did so to protect themselves from disease, and $33 \%$ $(27 / 82)$ to protect themselves from air pollution.

\section{Discussion}

This survey indicates that most Haji pilgrims were aware of the Ebola outbreak. Pilgrims who received travel advice were more informed than those who did not; however, $40 \%$ of pilgrims had no accurate knowledge of Ebola transmission. Almost all respondents adhered to hand washing several times a day, but less than half complied with hand hygiene after touching an ill person.

This study shows that $40 \%$ of the respondents saw a risk of Ebola at Hajj, but $45 \%$ pilgrims had no fear of contracting Ebola during Hajj. Those who were younger and/or had higher levels of education were more aware of Ebola. A survey from the United States showed that 
Respondents' compliance with preventative health measures during Hajj 2014, New South Wales, Australia, November 2014-February $2015(\mathrm{n}=134)$

\begin{tabular}{|c|c|c|c|c|c|}
\hline \multirow{2}{*}{ Preventative measures } & \multirow{2}{*}{$\begin{array}{l}\text { Uptake } \\
\text { n (\%) }\end{array}$} & \multicolumn{4}{|c|}{$\begin{array}{l}\text { Pilgrims' perception about the effectiveness of these measures } \\
\qquad(\%)\end{array}$} \\
\hline & & Very effective & $\begin{array}{l}\text { Moderately } \\
\text { effective }\end{array}$ & A little effective & Not effective \\
\hline Face mask use & $83(55)$ & $52(35)$ & $58(39)$ & $19(13)$ & $21(14)$ \\
\hline Hand hygiene & $148(99)$ & $107(71)$ & $29(20)$ & $10(7)$ & $4(3)$ \\
\hline Use of soap-based hand disinfectant & $111(74)$ & $56(37)$ & $45(30)$ & $16(11)$ & $33(22)$ \\
\hline Alcoholic hand disinfectant & $75(50)$ & $74(49)$ & $43(29)$ & $23(15)$ & $10(7)$ \\
\hline Avoiding contact with ill people & $65(43)$ & $67(45)$ & $56(37)$ & $18(12)$ & $9(6)$ \\
\hline
\end{tabular}

less educated respondents were more concerned about Ebola than those with better education [6].

Pilgrims who sought pre-travel health advice were more likely to be aware of Ebola and to practise hygienic measures than those who did not seek advice. A large Geo Sentinel study has confirmed that travellers who received pre-travel health advice were less likely to contract infectious diseases [7]. This survey shows that two thirds of pilgrims received some form of pretravel advice and only one sixth received formal pretravel advice despite the fact that all pilgrims routinely need to contact healthcare for mandatory vaccinations. This may indicate that although pilgrims visit GPs for vaccinations, formal pre-travel advice or sufficiently long interaction between the healthcare providers and travellers is rare. A previous survey by our team demonstrated that tour operators play an important role in providing Hajj pilgrims with advice on vaccination [8]. A study in the United Kingdom showed that community leaders (e.g. Imams) are important motivators of health promotion measures [9]. Direct engagement with the tour operators and community leaders could help reach the pilgrims with better pre-travel advice.

Adherence of hand hygiene among participants with just water was high (99\%), however fewer participants (74\%) reported using soap, and compliance with hand washing after touching an ill person was low (55\%). The difference between soap use and plain water could reflect Muslims' daily practice of washing their hands, faces and nostrils five times a day before ritual prayer [10]. According to the European Centre for Disease Prevention and Control (ECDC), hand hygiene is strongly recommended for travellers who travel to or in countries affected by Ebola outbreak [11]. Compliance with the use of face mask was also low (55\%). These findings are in agreement with a review by Benkouiten et al. who found that compliance of Hajj pilgrims was high for hand hygiene but not for use of face masks [12].

A large proportion of pilgrims reported that mass media was their main source of Ebola knowledge. It has been demonstrated that social media activity increases during an outbreak and the main influencers of the activity were news media outlets (e.g. CNN, Yahoo, Reuters) [13]. However, social media (e.g. twitter) were also found to be the dominant source of misinformation on Ebola [14]. Therefore, public health authorities should be encouraged to influence social media feeds through integration of correct health education with mass media. Studies involving pilgrims from other countries have shown that pilgrims' exposure to health messages can improve their engagement in protective measures [15] and direct health education for pilgrims is another effective way of improving their knowledge on preventive measures [16].

Although the findings from this survey cannot be generalised for all travellers, they provide important information about the knowledge about Ebola and hygiene practices of participants of one of the world's largest annual mass gatherings. Also, it should be noted that, at the moment, the risk of Ebola at Hajj is only theoretical and there are many other common infections that are preventable (e.g. by vaccination) but often take a heavy toll [17]. More importantly, the risk of Middle East Respiratory Syndrome coronavirus (MERS$\mathrm{CoV}$ ) remains a concern, while, according to a survey conducted early last year, only $35 \%$ of the Australian Hajj pilgrims were aware of the MERS-CoV epidemic in Saudi Arabia [18]. Public health authorities, media and GPs should encourage the travellers to seek formal travel health advice to prevent those infections. Further studies are needed to analyse this and formulate strategies to keep the travellers informed about infectious diseases.

\section{Conflict of interest}

Professor Robert Booy has received funding from vaccine manufacturers; the other authors have declared no conflict of interest in relation to this work. 


\section{Authors' contributions}

Amani S Alqahtani: designing the study, data collection, analysing data and drafting the manuscript. Harunor Rashid: designing the study, supervising data analysis and revising all versions of the manuscript. Kerrie E. Wiley, Harold W. Willaby, Nasser F. BinDhim, Mohamed Tashani, Anita E. Heywood and Robert Booy: substantial contribution to study design, and drafting and editing the manuscript.

\section{References}

1. Tosh PK, Sampathkumar P. What clinicians should know about the 2014 Ebola outbreak. Mayo Clin Proc. 2014;89(12):17107. http://dx.doi.org/10.1016/j.mayocp.2014.10.010 PMID:25467644

2. World Health Organization (WHO). Ebola situation report - 18 March 2015. Geneva: WHO. [Accessed 20 Mar 2015]. Available from: http://apps.who.int/ebola/current-situation/ ebola-situation-report-18-march-2015

3. Memish ZA, Al-Tawfiq JA. The Hajj in the time of an Ebola outbreak in West Africa. Travel Med Infect Dis. 2014;12(5):4157. http://dx.doi.org/10.1016/j.tmaid.2014.09.003 PMID:25257580

4. Tseng CP, Chan YJ. Overview of Ebola virus disease in 2014. J Chin Med Assoc. 2015;78(1):51-5. http://dx.doi.org/10.1016/j. jcma.2014.11.007 PMID:25547820

5. Wang M, Barasheed O, Rashid H, Booy R, El Bashir H, Haworth $\mathrm{E}$, et al. A cluster-randomised controlled trial to test the efficacy of facemasks in preventing respiratory viral infection among Hajj pilgrims. J Epidemiol Glob Health. 2015. Forthcoming. http://dx.doi.org/10.1016/j.jegh.2014.08.002

6. McCarthy M. Four in 10 US people fear large outbreak of Ebola. BMJ. 2014;349:g5321. http://dx.doi.org/10.1136/bmj.g5321 PMID:25163929

7. Schlagenhauf P, Weld L, Goorhuis A, Gautret P, Weber R, von Sonnenburg F, et al.; EuroTravNet. Travel-associated infection presenting in Europe (2008-12): an analysis of EuroTravNet longitudinal, surveillance data, and evaluation of the effect of the pre-travel consultation. Lancet Infect Dis. 2015;15(1):55 64. http://dx.doi.org/10.1016/S1473-3099(14)71000-X PMID:25477022

8. Barasheed O, Rashid H, Heron L, Ridda I, Haworth E, Nguyen Van-Tam J, et al.; Hajj Research Team. Influenza vaccination among Australian Hajj pilgrims: uptake, attitudes, and barriers. J Travel Med. 2014;21(6):384-90. http://dx.doi. org/10.1111/jtm.12146 PMID:25145836

9. Ahmed F, King R. Development and testing of a smoke-free homes intervention with Muslim faith leader in Leeds, UK. Lancet. 2012; 380:S22.

10. Allegranzi B, Memish ZA, Donaldson L, Pittet D, World Health Organization Global Patient Safety Challenge Task Force on Religious and Cultural Aspects of Hand HygieneWorld Alliance for Patient Safety. Religion and culture: potential undercurrents influencing hand hygiene promotion in health care. Am J Infect Control. 2009;37(1):28-34. http://dx.doi. org/10.1016/j.ajic.2008.01.014 PMID:18834738

11. European Centre for Disease Prevention and Control (ECDC). Rapid risk assessment: Outbreak of Ebola virus disease in West Africa, Ninth update, 30 January 2015. Stockholm: ECDC; August 2014. Available from: http://ecdc.europa.eu/en/ publications/publications/rra-ebola-feb-2014.pdf

12. Benkouiten S, Brouqui P, Gautret P. Non-pharmaceutical interventions for the prevention of respiratory tract infections during Haji pilgrimage. Travel Med Infect Dis. 2014;12(5):42942. http://dx.doi.org/10.1016/j.tmaid.2014.06.005 PMID:24999278

13. Househ M. Communicating Ebola through social media and electronic news media outlets: A cross-sectional study. Health Informatics ]. 2015; pii=1460458214568037. [Epub ahead of print]. PMID:25656678

14. Oyeyemi SO, Gabarron E, Wynn R. Ebola, Twitter, and misinformation: a dangerous combination? BMJ. 2014;349:g6178. http://dx.doi.org/10.1136/bmj.g6178 PMID:25315514

15. Balaban V, Stauffer WM, Hammad A, Afgarshe M, Abd-Alla M, Ahmed Q, et al. Protective practices and respiratory illness among US travelers to the 2009 Hajj. J Travel Med. 2012; 19: 163-8.

16. Turkestani A, Balahmar M, Ibrahem A, Moqbel E, Memish ZA. Using health educators to improve knowledge of healthy behaviour among Hajj 1432 (2011) pilgrims. East Mediterr Health J. 2013;19(Suppl 2):S9-12. PMID:24673092
17. Charrel RN. Hajj, Umrah, and other mass gatherings: which pathogens do you expect? Beware of the tree that hides the forest! Travel Med Infect Dis. 2014;12(5):418-9. http://dx.doi. org/10.1016/j.tmaid.2014.09.002 PMID:25241204

18. Tashani M, Alfelali M, Barasheed O, Fatema FN, Alqahtani A, Rashid H, et al. Australian Hajj pilgrims' knowledge about MERS-CoV and other respiratory infections. Virol Sin. 2014;29(5):318-20. 